\title{
The influence of a course in inclusive education on changing pre-service teachers' readiness to work with students with SEN
}

\section{Elena Marin}




\title{
The influence of a course in inclusive education on changing pre-service teachers' readiness to work with students with SEN
}

\author{
Elena Marin ${ }^{a^{*}}$ \\ ${ }^{a}$ University of Bucharest, Faculty of Psychology and Educational Sciences, Șoseaua Panduri nr. 90, sector 5, Bucharest, Romania \\ *Corresponding author: elena.marin@fpse.unibuc.ro
}

\section{Abstract}

\section{Keywords:}

Inclusive education; initial teacher training; attitudes and believes; university.
Understanding teachers' perspective towards inclusive education is seen as a decisive factor in making schools more inclusive. Given the increasing need to prepare pre-service teachers to face inclusion in the classroom as soon as they enter the teaching career, we consider appropriate to assess to which extend can a training course have an impact on the level of pre-service teachers to teach in inclusive classrooms. In this respect, final year students from Education Science degree that finalized a study course on the topic of inclusive education were invited to participate into this research by filling in a questionnaire based on the teacher efficacy for inclusive practices (TEIP) scale. Results show that even after taking a relatively short training course, it can bring about some statistically significant changes in pre-service teachers' knowledge, attitudes and confidence level towards inclusion. Pre-service teachers that have participated to this study are generally in favor of going through training courses to acquire a special set of skills to thereby be able to work in an inclusive learning environment.

\section{Zusammenfasung}

\section{Schlüsselworte:}

Inklusive Bildung;

Lehrererstausbildung;

Einstellungen und

Überzeugungen; Universität.
Das Verständnis der Perspektive von Lehrkräften in Bezug auf inklusive Bildung wird als entscheidender Faktor angesehen, um Schulen inklusiver zu machen. Angesichts der zunehmenden Notwendigkeit, Lehramtsstudierende auf die Integration in den Unterricht vorzubereiten, sobald sie in die Lehrtätigkeit eintreten, halten wir es für angemessen zu beurteilen, inwieweit eine Ausbildung einen Einfluss auf das Niveau der Lehramtsstudierenden haben kann in inklusiven Klassenzimmern. In diesem Zusammenhang wurden Studierende des Abschlusssemesters des Studiengangs Erziehungswissenschaften, die einen Studiengang zum Thema inklusive Bildung abgeschlossen hatten, eingeladen, an dieser Forschung teilzunehmen, indem sie einen Fragebogen auf der Grundlage der Skala der Lehrereffizienz für inklusive Praktiken (TEIP) ausfüllen. Die Ergebnisse zeigen, dass selbst nach einer relativ kurzen Ausbildung einige statistisch signifikante Veränderungen des Wissens, der Einstellung und des Vertrauensniveaus der Lehrkräfte in Bezug auf Inklusion bewirkt werden können. Lehramtsstudierende, die an dieser Studie teilgenommen haben, befürworten im Allgemeinen die Teilnahme an Schulungen, um spezielle Fähigkeiten zu erwerben, um so in einer inklusiven Lernumgebung arbeiten zu können.

\section{Introduction}

Understanding teachers' perspective towards inclusive education is seen as a decisive factor in making schools more inclusive. Studies show that preservice teachers have conflicting opinions regarding educating students with special education needs (SEN), mainly that it is seen as an extra duty (Van Reusen, et al. 2001). Within the Romanian context, a study showed that teachers say they have little or no clear information on the concept of inclusion, which could have a negative consequence on the process of developing an inclusive school education system (Marin, 2016). Therefore, a system of initial and continuing training must be implemented that meets the current requirements of pre-service teachers, providing compulsory courses in the field of inclusive education to all the pre-service teachers regardless of their specialization. That is why it is vital to start early, and by this we refer to prepare preservice teachers during their initial teacher training programme to face inclusion in the classroom. This assumption is based on different research that point out that teachers' broad epistemological beliefs may affect their assumptions about ability and disability (Jordan et al, 2009) and that teachers' attitudes often vary according to the type or severity of the disability (Levins, et al. 2005). 


\section{Theoretical foundation}

\subsection{Inclusive Education in Romania}

Education is recognized as one of the fundamental human rights and has been included in the United Nations Convention on the Rights of Persons with Disabilities. The movements of organizations and people with disabilities in the late '60s triggered a change in society's attitude (including at the legislative level) towards people with special educational needs (SEN). Inclusive education has established itself not only as modern educational alternatives, but has become, in the last 20 years, a reality of the Romanian educational system. This process of inclusion is primarily found in the acceptance of diversity. Encouraging the conditions of acceptance means an intervention from the beginning in reducing possible barriers. According to the Education Law (Romanian Education Law1/2011), the inclusion of the children with special educational needs can be done in different ways, such as:

- Within distinct educational institutions, entirely dedicated to education and training of children with special educational needs (separated special education);

- Groups and classes for children with special educational needs organized within mainstream education institutions (partially integrated special education);

- Within groups and classes organized in mainstream education institutions (full integrated special education).

At the same time, a number of measures were taken in order to support the inclusion process. According to Eurydice platform, in the report Special Education Needs Provision within Mainstream Education (2019) some amongst the measures are the following:

Figure 1. Implemented measures in order to support the inclusion process in Romania
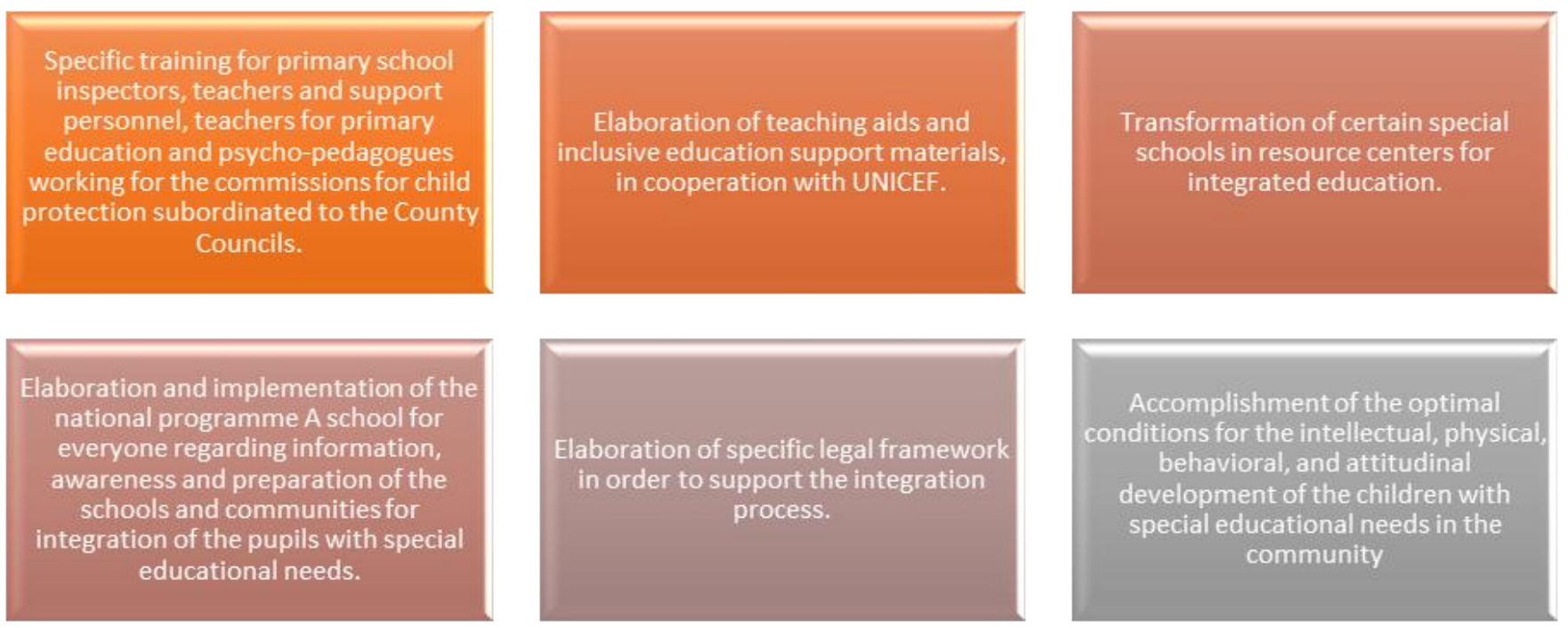

There are different support services for children with special education needs integrated into mainstream schools. Amongst the support services/measurements, the OECD report focuses on a wide description of the support or itinerant teachers (OECD, 2006). The support or itinerant teachers are recruited from among: pedagogues, psychologists and psycho-pedagogues, speech therapy teachers from the speech therapy interschool centers, special psychopedagogue teachers from special schools and teachers from mainstream schools trained through special courses. A teacher from the mainstream system may become a support or itinerant teacher in a variety of ways: by graduating from special courses, completing some form of evaluation and selection or by completing a limited period probation. The support or itinerant teacher has responsibilities such as identifying the need for support in the classroom, done at the request of the teacher that sees the need during activities carried on by the school support team and organizing preliminary "exploration" meetings with the target group of children outside of the classroom in order to identify non-intellectual factors that contribute to school failure.

Taking into consideration the presence of multiple school specialist that work together to foster an inclusive education system, the Romanian general 
objectives of partially or fully inclusive education are as follows:

Figure 2. General objectives of inclusive education

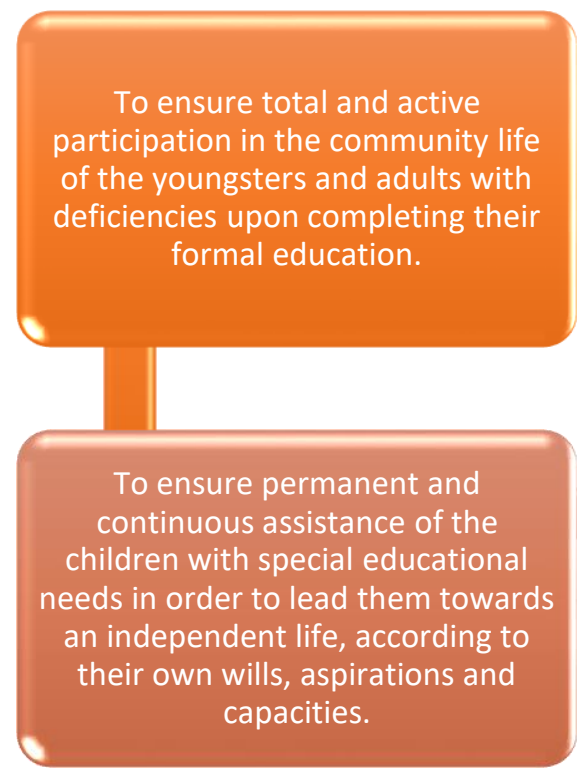

2.2. How do Teacher Training Programmes respond to the need to train pre-service teachers to face inclusion in the classroom?

In Romania, pre-service (initial) teacher training focuses on training for a chosen specialty but is less developed in terms of preparing from a didactical/pedagogical approach, including insufficient aspects such as modern teaching methods, cooperative teaching, class management and conflict resolution. Therefore, after graduation, Romanian teachers are good specialists in their field, but not very good learning facilitators. There is a need for a longer period of training practice before entering the teaching profession.

For secondary school teachers, pre-service teacher training is organized in universities, under the concurrent teaching training programme and is organized in a module that includes subjects, such as: psychology, pedagogy, child psychology and the methodology of the teaching and learning process for their specialty. The initial training of teachers who will work in special education consists of a particular training in this field, a study programme entitled Special education.

Marin (2020) presents a proposal so that all preservice teachers will benefit from training in the field of inclusive education. Thus, it is considered necessary to insert in the disciplines of fundamental psychopedagogical training the study discipline Inclusive education. In addition to the four disciplines of fundamental psycho-pedagogical training (Psychology of education; Pedagogy I; Pedagogy II; Student class management) it is recommended to insert the study discipline Inclusive education. That is how pre-service teachers, regardless of the field of study, can benefit, in the initial training phase, of courses that familiarize them with specific inclusive educational terminology, and can allow access to models of analysis and operational action in inclusive educational context. Pre-service teachers can develop a positive attitude towards the issue and practice of educational inclusion and can benefit from successful practice models of educational inclusion.

Also, the Ministry of National Education in Romania considerers that the inclusion support measures need to be further developed and that they should address the following issues: training of educational specialist in order to better prepare mainstream schools to integrate pupils with special educational needs. According to the Eurydice country report (2019), preparation should be provided from a multi- level perspective: 
Figure 3. Pre-service teachers` training from a multi- level perspective

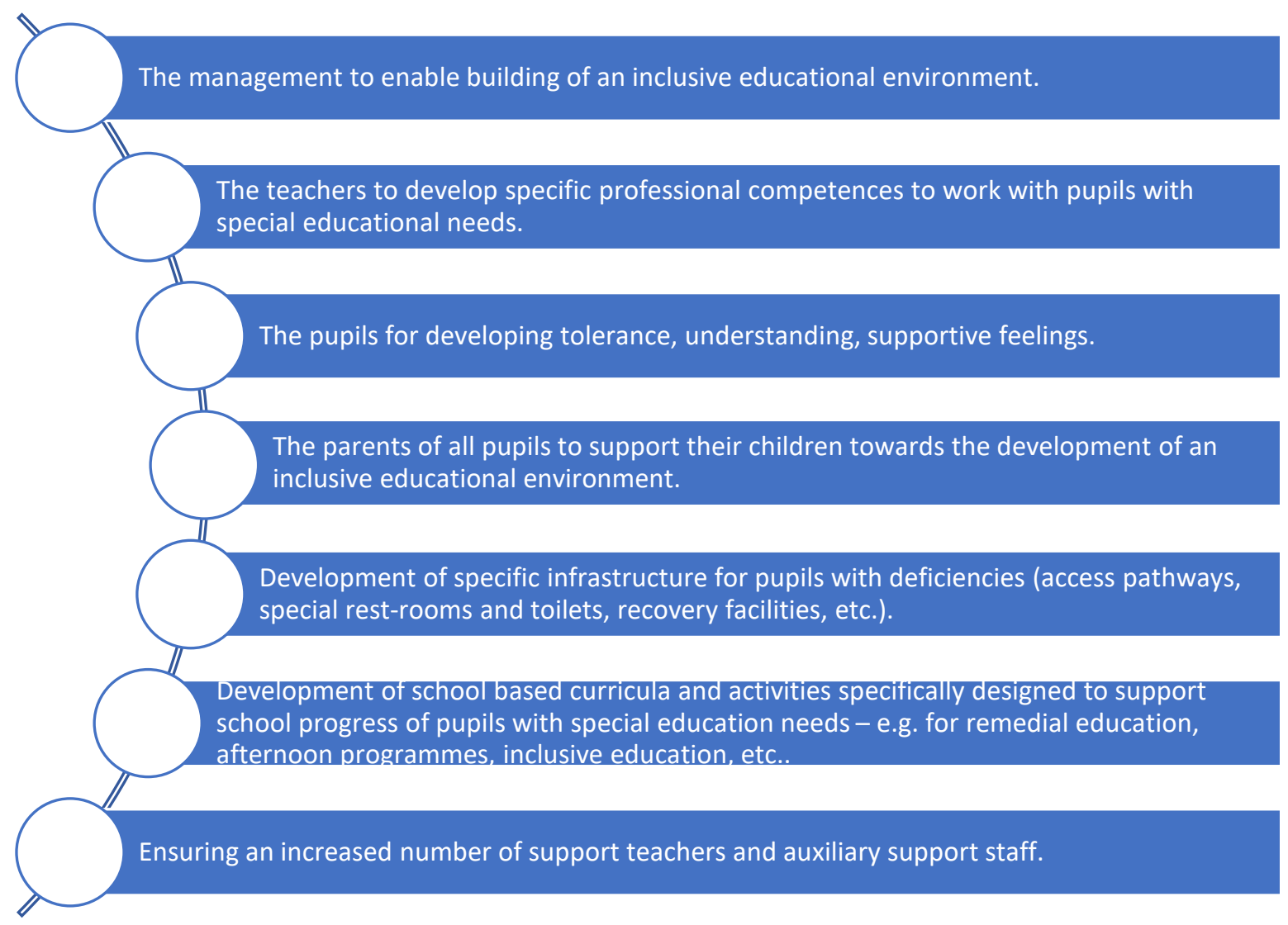

\section{Research methodology}

Given the increasing need to prepare pre-service teachers to face inclusion in the classroom as soon as they enter the teaching career, we consider appropriate to assess to which extent a training course on the topic of inclusive education, entitled "Special education needs. Evaluation and intervention" can have an impact on the level of readiness of pre-service teachers to teach in inclusive classrooms. In this respect, the use of "the teacher efficacy for inclusive practices TEIP scale" was used to measure perceived student teacher efficacy to teach in inclusive classrooms (as previously sustained also by Loreman, Sharma \& Forlin, 2013).

The sample was comprised of third-year students enrolled in the Educational Sciences BA programme and who finalized a 10-week study course (that is compulsory in their training) on the topic of inclusive education, entitled "Special education needs. Evaluation and intervention" ( $n=64)$. The data was collected at the end of the course during 3 different generations. The pre-service teachers were invited to participate into this research by filling in the TEIP questionnaire. The teacher efficacy for inclusive practices (TEIP) scale is designed to measure perceived teacher efficacy to teach in inclusive classrooms (Sharma, Loreman \& Forlin, 2013). The scale consists of 18 items scored on a six-point Likert scale $(1=$ strongly disagree, $2=$ disagree, $3=$ disagree somewhat, $4=$ agree somewhat, $5=$ agree and $6=$ strongly agree). To analyze the gathered data, we used SPSS 19 and measured the frequencies of the responses given.

\section{Results}

Results show that pre-service teachers who have participated in this study are willing to go through training courses to acquire new knowledge related to teaching and learning design to adapt to diversity in the classroom, and a special set of skills to be able to work in an inclusive learning environment. We focused the results on the dimensions presented below, that are related to teachers' readiness to implement an inclusive school environment.

\subsection{Pre - service teachers' ability to design and} implement a personalized learning process

In terms of instructional design process, preservice teachers need to know how to modify and improve the basic curriculum to give students full access to it. As pointed below, around $37 \%$ of pre- 
service teachers agree that are feeling somehow prepared to adapt the learning content, whereas approximately $50 \%$ of them say that are ready to face the challenges of adapting the curriculum and learning opportunities so that the SEN children could benefit of a meaningful learning experience. Only a small percentage of pre-service teachers consider themselves fully prepare to face inclusion in the classroom, and this result can be corelated with the fact that they do not have a full teaching experience so far, just the one year practicum that is taking part during their second year of study.

Figure 4. Pre-service teachers' ability to design meaningful and personalized learning tasks

I am confident in designing le arning tasks so that the individual needs of students with disabilities are accommodated.

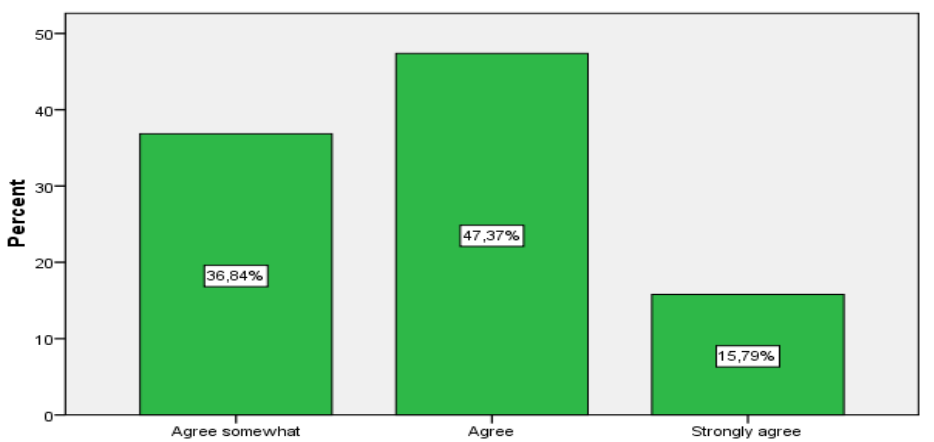

4.2. Pre - service teachers' ability to enhance collaboration and managing conflict situation in the classroom

Working in groups has clear advantages for students, but for teachers this task may come with challenges, such as monitoring students' task behavior, managing group time, providing relevant materials, assigning individual roles, and establishing beliefs and teamwork behavior. That is why during the training course pre-service teachers were invited to experience some activities where they had to prepare and implement some collaborative learning experiences, with a great emphasize on the dynamics and enhancing each student potential withing the working group. That is why it is important to see the level of confidence preservice teachers have when it comes to designing and implementing group activities with their pupils. As pictured below, a great majority of them (57\%) strongly agree with the fact that they feel confident in getting their pupil/students to work in groups.
Figure 5. Pre-service teachers`ability to promote pupils`collaboration

I am confident in my ability to get students to work together

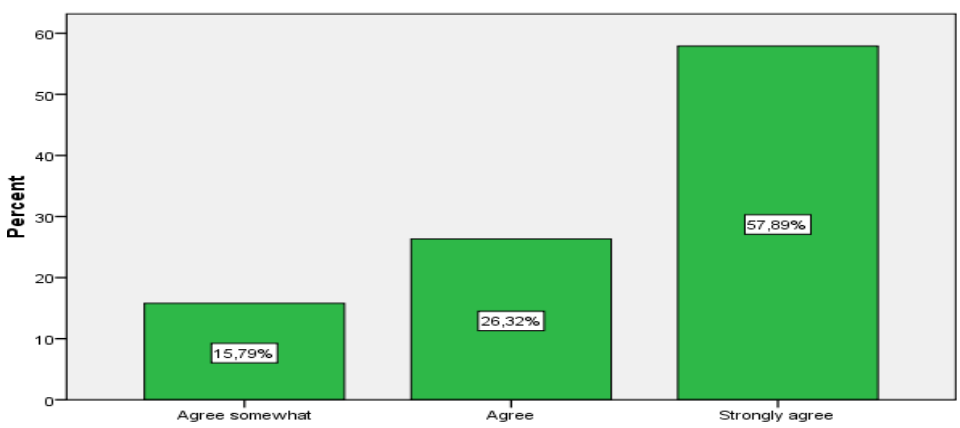

What pre-service teachers must always keep in mind is the fact that pupils can bring multiple perspectives to the classroom - diverse environments, learning styles, experiences and aspirations. This is why they must learn during in service teacher training practice about collaboration - that we must never assume a unique approach when working collaboratively. Moreover, when pupils work together in class, pre-service teachers must learn that it is their role and responsibility to have a direct and immediate sense of how their pupils are learning and what experiences and ideas they may bring to their work. At the same time, it is important to constantly look at the possibility of facing face challenges while structuring collaborative activities, such as monitoring students' behavior, managing group working time, providing relevant materials, assigning individual roles, and establishing beliefs and teamwork behaviors. And for this reason, it is necessary for pre-service teachers to know how to prevent disruptive behaviors, and as showed below the respondent feel somehow (21\%) confident in their ability to deal with unwanted behavior. At the same time, more than half of the preservice teachers agree with that fact that they feel confident in preventing and controlling, if needed, disruptive behavior in the classroom.

Figure 6. Pre-service teachers' ability to control disruptive behaviour in the classroom

I can control disruptive behaviour in the classroom.

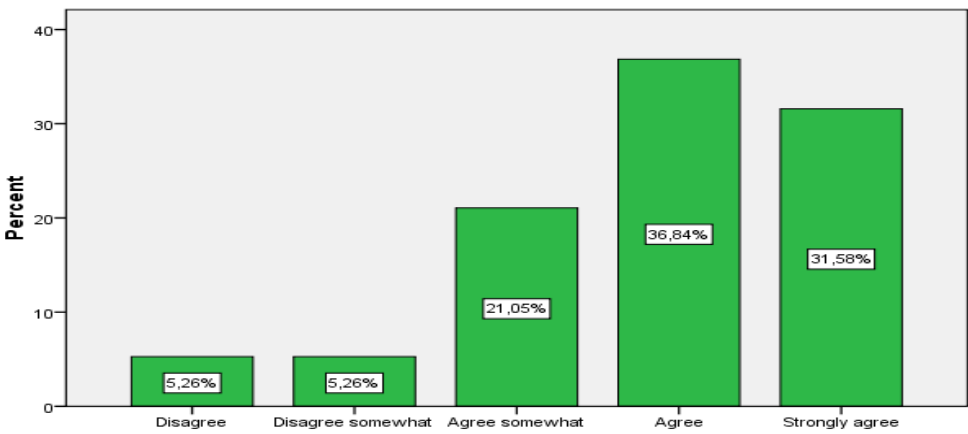




\subsection{Pre - service teachers' ability to assist families} so that their children do and feel well in schools

Pre-service teachers need to understand the role of parents and work with them as partners to build trusting partnerships. It is crucial that both sides know what is expected of each other for more effective collaboration. It is worth mentioning that effective teacher-parent partnerships require a lot of patience, planning and implementation structure. Also, the collaboration as a creative partnership can be used by education practitioners and parents to achieve inclusion in a mainstream. That is why it is important to equip pre-service teachers with the necessary skill to create a strong collaboration with parents in schools. This said, the respondents participating in this study feel that they are ready in a moderate and high degree (almost $70 \%$ of respondents) to assist families in helping children do well in schools. 5,2\% of respondents do not feel prepared to assist families, whereas $21 \%$ say that they are feel somehow ready to establish a fruitful collaboration with parents, in order to support further cognitive and non-cognitive development of children.

Figure 7. Pre-service teachers' ability to assist families in helping their children in school

I can assist families in helping their children do well in school.

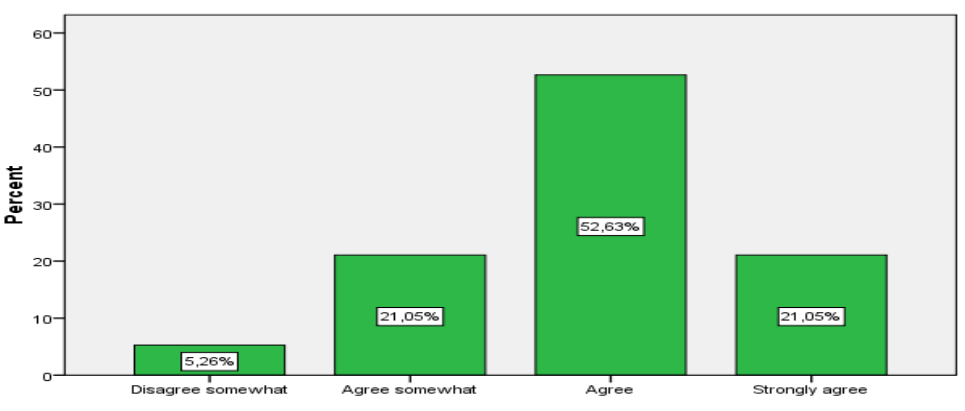

4.4. Pre - service teachers' professional development - collaboration with peers

As we all know, pupils learn best when materials and instructions are not isolated and therefore, counselors can have a great impact by working with teachers to provide instruction that addresses content standards and school counseling standards. The teacher should share class time with the counselor so that classroom lessons can be offered on the development of academic, career and personal / social skills, and the teacher should allow out-of-class students to meet with the counselor individually or in small groups. when the counselor identifies several individual needs.
Figure 8. Pre-service teachers' ability to work jointly with other education professionals and staff

I am able to work jointly with other professionals and staff (e.g., aides, othe
teachers) to teach students with disabilities in the classroom.

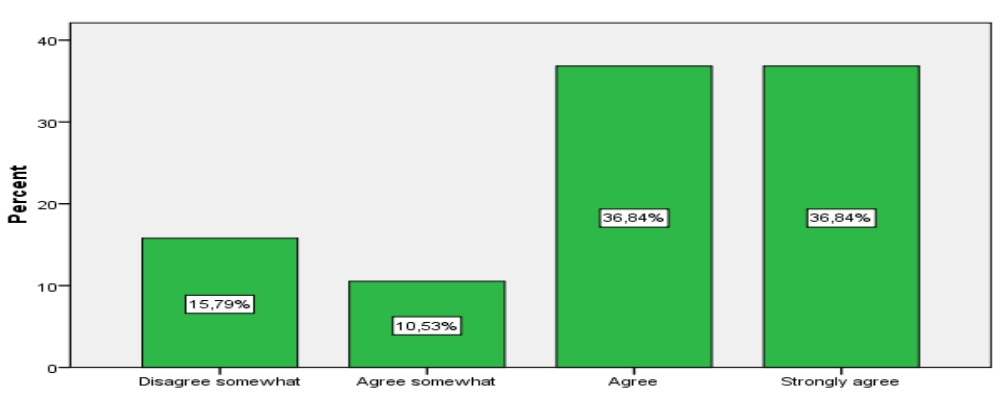

These are the principals that demonstrate the importance of training pre-service teachers to know the importance of peer collaboration from strategies of communication, to dealing with potential conflict and more than that to keep in mind the advantages that peer-collaboration bring to children' development. Taking into consideration the fact that the respondents are somehow acquainted with other colleges that are training as SEN specialists, the rusts mostly indicate (approximately 76\%) that they are in favor of establishing a collaboration with other professionals and see this task as being able to fulfill it. Still, 15,79\% of respondents somehow disagree with the fact that they are prepared to work jointly with other professionals, and $10,53 \%$ agree up to a certain point that they consider themselves ready to establish strong collaboration partnerships.

\subsection{Pre-service teachers' assessment skills}

Assessment represents a heavy demand on preservice teacher content and pedagogical knowledge of teachers. Classroom assessment involves a wide range of activities and the nature of the assessment is depended on the class levels and content areas necessary to teach. This topic is one of the most debated across teacher training study programme due to the level of its complexity. That is why is important to prepare pre-service teachers to feel ready to make use of a variety of assessment strategies, such as portfolios, using standardized test and knowing how to interpret the results or implementing an on-going performance - based assessment. As seen in the graph below, approximately $50 \%$ of respondents say that they are ready to implement an evaluation system that address the pupils` needs, where as $31 \%$ of them think that there is still some work to be done in order to feel ready to give their pupils the chance to have a solid build evaluation process. 
Figure 9 Pre-service teachers' ability to use a varied assessment strategy I can use a variety of asse ssment strategies (for example, portfolio
assessment, modified tests, performance-based assessment, etc.).

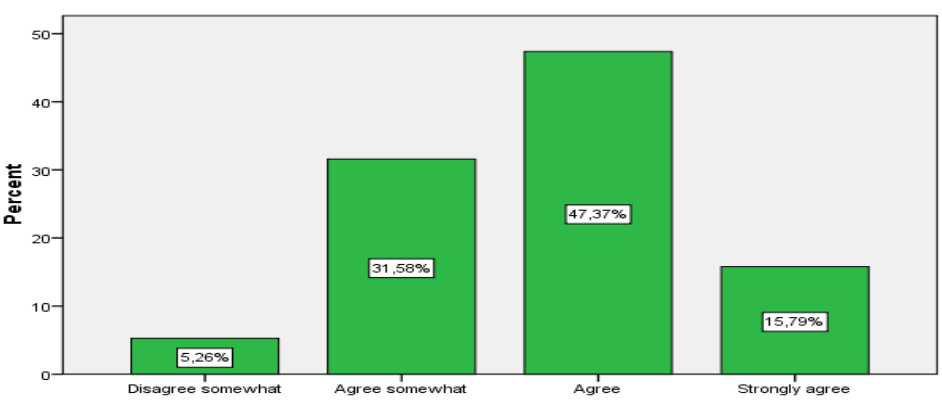

\section{Discussion and conclusion}

The main purpose of this paper was to assess the relevance of an inclusive education teaching course focusing on the pre-service teachers' readiness to work with students with SEN after taking a 10 week course. First, we consider necessary to maintain the existing initial teacher training systems in Bologna, which is implemented at national level, but more importance should be given to the introduction of a course of study that prepares all pre-service teachers for inclusive education. The idea according to which pre-service teachers have to go through a series of training courses in order to prepare them to face inclusion in the classroom is also related to the need of acquiring a special set of skills so that they will be able to work in an inclusive learning environment (Marin, 2017).

The results presented above show that even after taking a relatively short training course, it can bring about some statistically significant changes in preservice teachers' knowledge, attitudes and confidence level towards inclusion. Data points out that preservice teachers in general tended to be less reluctant to include students with SEN, but they became more concerned about provision of support and resources which, if unavailable, might hinder their perceived performance, and that of the school and other students. These results are consistent with the past research (Avramidis et al., 2000); Campbell, Glimore \& Cuskelly, 2003; Forlin \& Chambers, 2011; Sharma \& Chow, 2008).

Moreover, the present research findings show that by raising pre-service teachers' awareness alone is insufficient and that is why participating in training in the field of inclusive education is compulsory. Preservice teachers that have participated to this study are generally in favor of going through training courses to acquire a special set of skills to thereby be able to work in an inclusive learning environment which correlates to the findings of the OECD report that shows that teacher's opinion towards their own professional development is commonly related to the need to acquire new knowledge related to didactics and on how to adapt to diversity in the classroom (OECD, 2005). But this is not enough, still a great majority of the respondents stating that somehow, they do not feel very comfortable with the responsibility that comes together with the development of an inclusive classroom environment. This result is similar to the findings of another study related to pre-service primary and secondary teachers that shows that a third of them consider themselves still having uncertainty regarding terminology use or they fell the lack of support for an inclusive classroom setting even after taking a course in inclusive education (McCray \& McHatton, 2011). Also, developing pre- and in-service training programs can play a significant role in preparing future education professionals in order to enhance their knowledge and skills in teaching all students and facilitate the development of positive attitudes and beliefs (Borg et al., 2011)

All in all, this study indicates that a particular topic of inclusive education cannot just be enough to instill the beliefs needed for inclusive teaching. Moreover, the process of inclusion of children with SEN does not needs to provide adequate support to the students in the class and it also needs to provide assistance for the teachers that are teaching in that class. This support is needs to start early, from the teacher training programme, continue across the first years of practice of a newly qualified teachers, and why not, to all the teachers and school specialists who need assistance in adopting inclusive practices and implementing them.

\section{Limitation}

An important aspect regarding this research is related to the fact that we must look carefully at the significance of the results obtained in this research as they show a very limited reality, that of students in the third year of bachelor degree in Educational Sciences from the University of Bucharest. What this data indicates us is that in order to develop real inclusive education values, other aspects must also be taken into consideration, such as the fact that because the students' teachers were not already teachers with full responsibility, they may not have the freedom to put all the things they wanted to into practice. 


\section{Authors note:}

Elena Marin is lecturer at the Faculty of Psychology and Educational Sciences, University of Bucharest. She graduated with a double degree in Education Sciences and also in Psychology, holds a Master in School Counseling and Career Development and $\mathrm{PhD}$ in Education Sciences from The University of Bucharest. As a lecturer she coordinates the seminars of Instructional Theory, Classroom management, Inclusive education and also the Pedagogy course in the Teacher Training Department. Her main focus is on initial teacher training system, teacher mobilization, inclusive education and the social dimension of Higher Education.

\section{References}

Avramidis, E., Bahlise, P., \& Burden, R. (2000). A survey into mainstream teachers' attitudes towards the inclusion of children with special educational needs in the ordinary school in one local education authority. Educational psychology, 20(2), 191-211.

Borg, G., Hunter, J., Sigurjonsdottir, B., and D'Alessio, S. (2011). Key Principles for Promoting Quality in Inclusive Education: Recommendations for Practice. Odense: European Agency for Development in Special Needs Education.

Campbell, J., Gilmore, L., \& Cuskelly, M. (2003). Changing student teachers' attitudes towards disability and inclusion. Journal of Intellectual and Developmental Disability, 28(4), 369-379.

Forlin, C., \& Chambers, D. (2011). Teacher preparation for inclusive education: Increasing knowledge but raising concerns. Asia-Pacific Journal of teacher education, 39(1), 17-32.

Jordan, A., Schwartz, E., \& McGhie-Richmond, D. (2009). Preparing teachers for inclusive classrooms. Teaching and Teacher Education, 25(4), 535-542.

Levin's, T., Bornholt, L., \& Lennon, B. (2005). Teachers' experience, attitudes, feelings and behavioral intentions towards children with special educational needs. Social Psychology of Education, 8(3), 329-343.

Lore man, T., Sharma, U. \& Forlin, C. (2013) Do preservice teachers feel ready to teach in inclusive classrooms? Australian Journal of Teacher Education, $38,27-44$.

Marin, E. (2016). Teachers' perspective towards the implementation of inclusive education, Journal of Educational Sciences. 1(33), 36-44.

Marin, E., (2017). The inclusive teacher - alternative routes for teacher training in the field of inclusive education. A Romanian perspective. Journal Plus Education, 17(1), 2068-1151.

Marin, E. (2020). Teacher training for the perspective of the inclusive educational system. Bucharest: University of Bucharest Publishing.

McCray, E. D., \& McHatton, P. A. (2011). Less afraid to have them in my classroom: Understanding pre-service general educators' perceptions about inclusion. Teacher Education Quarterly, 38(4), 135-155.

Sharma, U., \& Chow, E. W. (2008). The attitudes of Hong Kong primary school principals toward integrated education. Asia Pacific Education Review, 9(3), 380-391.

Van Reusen, A., Shoho, A., \& Barker, K. (2001). High school teacher attitudes towards inclusion. The High School Journal, 84(2), 7-17.

*** (2011). The Romanian Education Law. Available at: http://keszei.chem.elte.hu/Bologna/Romania_Law_of_N ational_Education.pdf

*** Eurydice. (2019). Special Education Needs Provision within Mainstream Education. Available at: https://eacea.ec.europa.eu/national-

policies/eurydice/content/special-education-needsprovision-within-mainstream-education-56_en

*** OECD. (2005). Teachers matter: Attracting, developing, and retaining effective teachers. OECD Publishing

*** OECD. (2006). Education Policies for Students at Risk and those with Disabilities in South Eastern Europe. Available at: https://www.oecdilibrary.org/docserver/9789264036161en.pdf?expires $=1595497847 \&$ id=id\&accname $=$ guest $\& \mathrm{c}$ hecksum=79D5F61CA1AC1FD4114C4EBF29734C65 